ENTREPRENEURSHIP AND SUSTAINABILITY ISSUES

ISSN 2345-0282 (online) http://jssidoi.org/jesi/

2020 Volume 7 Number 4 (June)

http://doi.org/10.9770/jesi.2020.7.4(21)

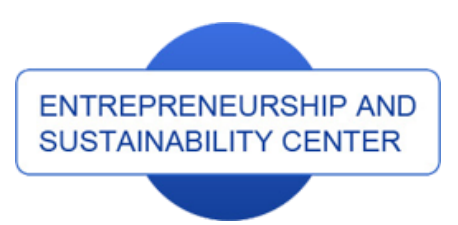

Publisher

http://jssidoi.org/esc/home
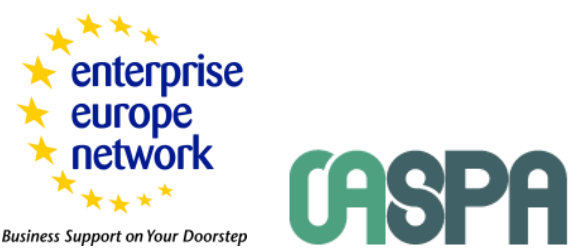

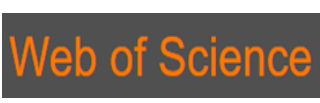

Clarivate

Analytics

\title{
GLOBAL CLIMATE CHANGE AND GREENHOUSE EFFECT
}

\author{
Alexey Mikhaylov ${ }^{1 *}$, Nikita Moiseev ${ }^{2}$, Kirill Aleshin ${ }^{3}$, Thomas Burkhardt ${ }^{4}$ \\ ${ }^{1}$ Financial University under the Government of the Russian Federation, 125167, Leningradsky Ave, 49, Moscow, Moscow, \\ Russian Federation \\ ${ }^{2}$ Plekhanov Russian University of Economics, Stremyanny Lane 36, 117997, Moscow, Russian Federation \\ ${ }^{3}$ Institute for African Studies, Russian Academy of Sciences, 123001, Spiridonovka str., 30/1, Moscow, \\ Russian Federation \\ ${ }^{4}$ Universität Koblenzlandau, Universitätsstraße 1, 56070, Koblenz, Germany \\ ${ }^{*}$ E-mail: $\underline{\text { alexeyfa@ya.ru }}$ (corresponding author)
}

Received 18 November 2019; accepted 25 February 2020; published 30 March 2020

\begin{abstract}
The climate has changed significantly under the influence of human behavior. And first of all, this is due to the change in the proportionality and concentration of greenhouse gases in the atmosphere (water vapor, carbon dioxide, methane, ozone, PFC (perfluorocarbons). This paper analyzes the dynamics of greenhouse gas emissions. Climate change has many consequences on human health throughout the world, especially in African countries. The growth of greenhouse gas emissions is viewed as a cause of infectious and non-infectious diseases, negative effects on nutrition, water security and other social disruptions. The global average temperature gradually increases, and the atmospheric $\mathrm{CO} 2$ concentration has exceeded $400 \mathrm{ppm}$ due to the intensification of greenhouse effect. The method of energy balance was featured to simulate the trends in Greenhouse Gas Emission Forecast in different sectors until 2030. Through sensitivity analysis, we found that the reduction of anthropogenic CO2 emissions from people (cars and households) would deescalate the consequences of the above trends. Emissions are mostly associated with industries, which can be reduced if local Government will want to achieve the Paris Agreement goal.
\end{abstract}

Keywords: global warming; emission reduction; greenhouse effect; climate change; greenhouse gases

Reference to this paper should be made as follows: Mikhaylov, A., Moiseev, N., Aleshin, K., Burkhardt, T. 2020. Global climate change and greenhouse effect. Entrepreneurship and Sustainability Issues, 7(4), 2897-2913. http://doi.org/10.9770/jesi.2020.7.4(21)

JEL Classifications: Q01, Q32

\section{Introduction}

Global climate change is an important problem in this time. It leads to a gradual increase in the average annual temperature of the planet, which began with the industrial revolution in the beginning of the XX century. Extreme weather in recent years has made the talks about the growth of Earth's temperature more intense. The change in temperature is explained by high levels of manufacturing and economic activity that includes emissions of main greenhouse gases: carbon dioxide, methane, etc. (Albergel et al., 2010). 


\section{ENTREPRENEURSHIP AND SUSTAINABILITY ISSUES}

ISSN 2345-0282 (online) http://jssidoi.org/jesi/

2020 Volume 7 Number 4 (June)

http://doi.org/10.9770/jesi.2020.7.4(21)

The climate system of the Earth covers the atmosphere, the ocean, the land, the cryosphere (ice and snow) and the biosphere. The figure suggests a visual representation of its components and operations of the process. The climate is described by such characteristics as temperature, the amount of precipitation, air humidity and soil, the state of the snow and ice cover, and many others. The climate is constantly changing due to many different natural factors. A significant new factor, which has been influencing the Earth's climate more and more in the last 200 years, has become human activity. Its impact is defined by the so-called greenhouse effect (Alirezaei et al, 2017; Bayer, 2015; Moumen et al., 2019; Chehabeddine, Tvaronavičienè, 2020).

An additional stumulation to its popularization in the 20th century was machine learning modeling of global temperature, which, according to reserchers, proved the anthropogenic greenhouse effect (Babic, 2017).

The introduction of this paradigm into the mass consciousness began in USA and Europe in the last century. This paradigm was a subject of many critiques after the 1997 Kyoto conference. Highly developed countries were determined there. They can create a general cataclism in the future, or, alternitavely, reducte green house emissions. It will stimulate the companies to more attentive research for global warming evidence (Bergamaschi, 2013).

Climate change has been caused by the influence of natural processes. However, anthropogenic influence factors are becoming significant in relation to global warming. There are two major reasons of global climate change: Earth's magnetic field changes and greenhouse gases in the lower levels of Earth's atmosphere (Chen and Chen, 2016).

According to last researches, the global temperature of the Earth grew $0.5-1{ }^{\circ} \mathrm{C}$ in the last 100 years. Moreover, it is reported that the total greenhouse gas emissions in Russia are likely 404.9 million metric tons of carbon dioxide, which is the equivalent to 0.0086154 metric tons per capita (Cui et al., 2016). There is an exclusion in the regions of sub-Saharan Africa from the global trade converges with the climatic productivity of agriculture.

In the past ten years, the problem of climate change caused by antropologic activities has become the most serious amongst environmental issues. This problem is also adjacent to population growth, deforestation, globalization, economic growth, production and consumption of industrial goods (Chen et al, 2015; Cloy, 2018).

\section{Literature review}

The calculations of the International Commission on Climate Change show that the average global temperature by the next century will rise by $6{ }^{\circ} \mathrm{C}$ if the current trends in the use of fossil fuels and deforestation are not reversed (Denisova et al., 2019; Elzan and Hohne, 2008; 2010).

Climate change also occurs in parallel and in combination with other pressured situations affecting global health, including widespread changes like globalizaiton. Furthermore, it is expected that the global population will increase more than 30 per cent by 2050. Such pressure often has a geographic specificity. For example, in subSaharan Africa, the increase of population growth leads to increased demand for natural resources which, in combination with regional exclusion from the global trade, damages the climatic productivity of agriculture. There is already disproportionately high infectious disease in the region, which becomes increasingly more dangerous if it is also participants in global environmental change and other serious and related problems (Denisova, 2019; Fan et al., 2010). 
A firm understanding of subject links and their differential effects, based on differential socio-economic conditions is needed to completely prepare and respond to current and short-term problems of climate change on health and societies. Moreover, it is necessary to develop and include new and effective preventive approaches of negating long-term negative health effects (Flolking et al., 2006).

A report of the Commission on Climate Change includes short-term investments in research, monitoring of climate change and health consequences, the adoption of mechanisms to facilitate intra- and intergovernmental cooperation with emphasis on the extent to which additional global environmental changes affect health outcomes. The report also discusses the processes of phasing from coal-fired power generation and transition to human and planetary cities (Gotovsky et al., 2018).

This research makes an important contribution to the body of knowledge on carbon emissions' forecasting. Furthermore, it works to complete the gap in research on the role of carbon emissions in climate change that remains a debate for previous researchers through empirical testing of mediating role aiming for no climate change in (Lopatin, 2019b; Meynkhard, 2019b; Meynkhard, 2020).

The greenhouse effect is an increase in the temperature of the earth's surface due to the heating of the lower layers of the atmosphere by the accumulation of greenhouse gases. As a result, the air temperature is greater than it should be, and this leads to such irreversible consequences as climate change and global warming (Huang et al., 2016).

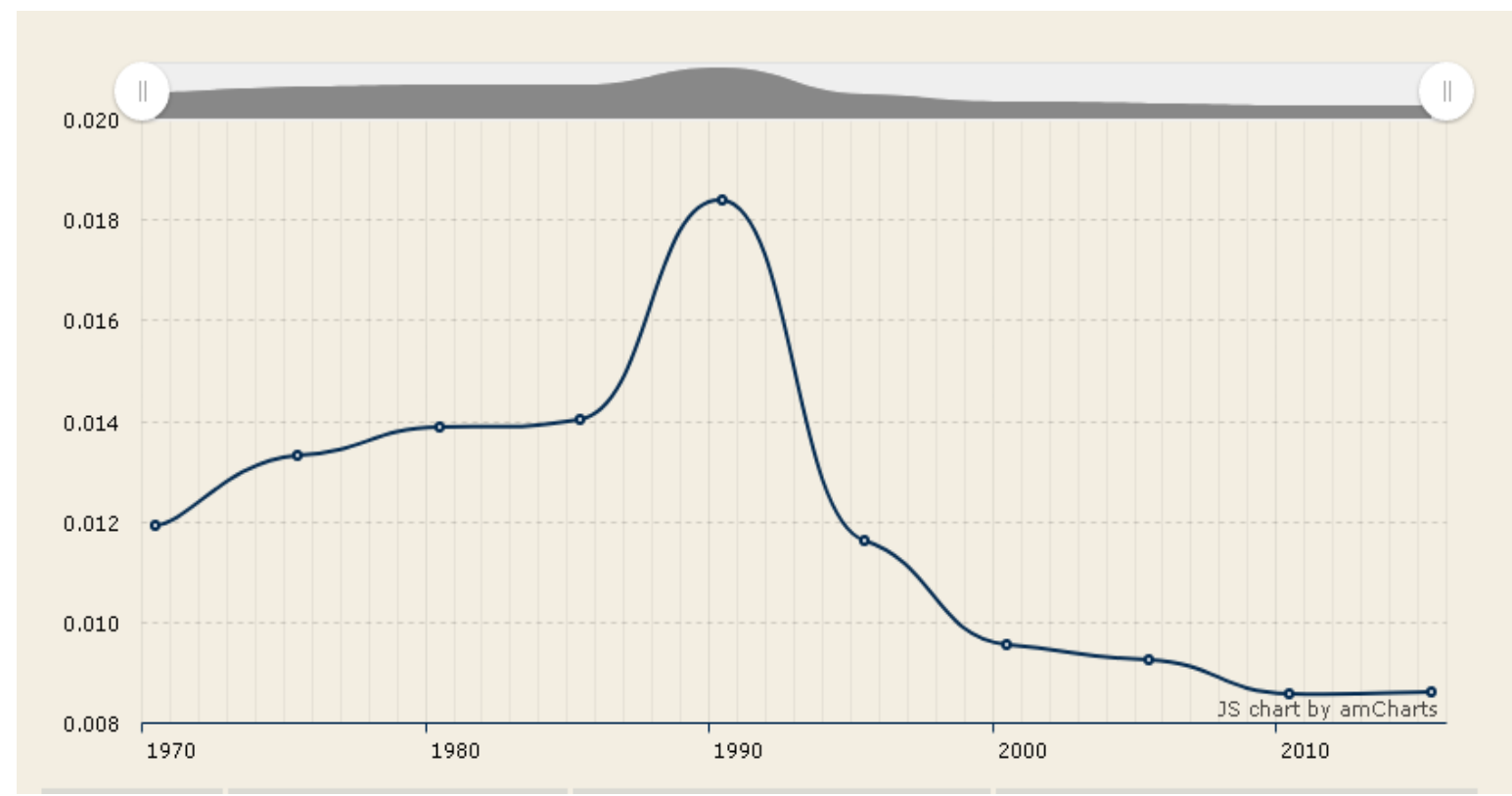

Fig. 1. Total greenhouse gas emissions (metric tons per person)

Source: European Environment Agency. https://www.eea.europa.eu/data-and-maps/data/greenhouse-gas-emission-projections-for-6

Discussions about the phenomenon first began in 1827. An article by Jean Baptiste Joseph Fourier "A note on the temperatures of the globe and other planets" detailed ideas about the mechanism of the greenhouse effect and the 
causes of its appearance on Earth (Inamdar, 1994). The latter conducted experiments with a blackened glass vessel closed and placed under sunlight. The temperature inside the vessel was much higher than outside. This is explained by the following factor: thermal radiation can not pass through the darkened glass, and therefore remains inside the container. In this case, the sunlight boldly penetrates through the walls, since the vessel remains transparent outside (Isacs et al., 2016; Kohler et al., 2017).

Table 1. Greenhouse gas summary

\begin{tabular}{|c|c|}
\hline Compound & Formula \\
\hline
\end{tabular}

$\begin{array}{lll}\text { Water vapor and clouds } & \mathrm{H}_{2} \mathrm{O} & 10-50,000^{(\mathrm{A})}\end{array}$

\begin{tabular}{cccc}
\hline Carbon dioxide & $\mathrm{CO}_{2}$ & $\sim 400$ & $9-26 \%$ \\
\hline Methane & $\mathrm{CH}_{4}$ & $\sim 1.8$ & $4-9 \%$ \\
\hline Ozone & $\mathrm{O}_{3}$ & $2-8^{(\mathrm{B})}$ & $3-7 \%$ \\
\hline Source: European Environment Agency https://www.eea.europa.eu/data-and-maps/data/greenhouse-gas-emission-projections-for-6
\end{tabular}

The causes of the greenhouse effect are as follows: the use of combustible minerals in industries - coal, oil, natural gas, which emits a huge amount of carbon dioxide and other harmful compounds into the atmosphere when burned; different means of transportation - cars and trucks emit exhaust fumes that also pollute the air and enhance the greenhouse effect; deforestation, which absorbs carbon dioxide and releases oxygen, and with the destruction of each tree on the planet the amount of CO2 in the air increases; forest fires are another source of plant destruction on the planet (Table 1). The increase in population affects the growing demand for food, clothing, housing. Correspondingly, on order to comply with this demand industrial production is growing, which is increasingly polluting the air with greenhouse gases; agro chemistry and fertilizers contain a different number of compounds, the evaporation of which releases nitrogen - one of the greenhouse gases; decomposition and burning of garbage at landfills contributes to the increase of greenhouse gases (Levin, 2012; Li, 2017; Lisin, 2020).

\section{Materials and methods}

In Northern Europe, especially in the Baltic region, the amount of surface and channel flow may increase exponentially (Lopatin, 2019a; Meynkhard, 2019a). 


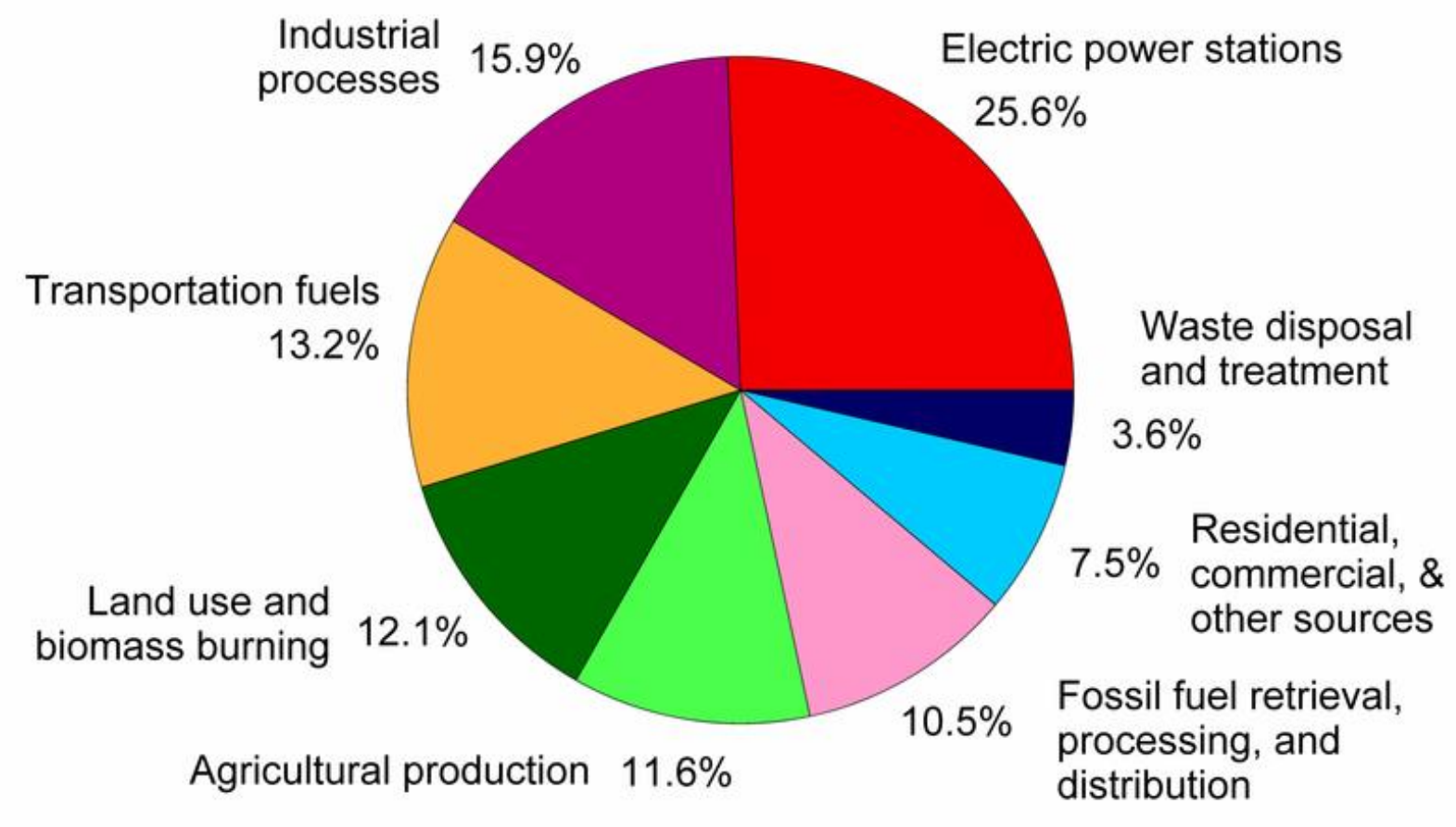

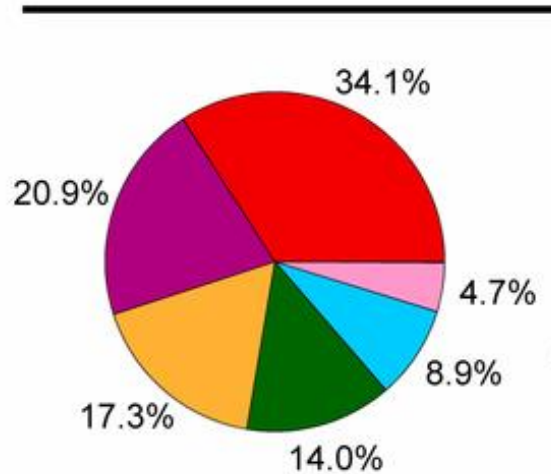

Carbon Dioxide

$(72 \%$ of total)

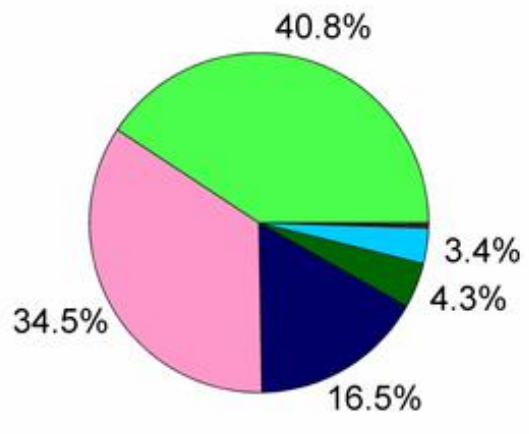

Methane

( $20 \%$ of total)

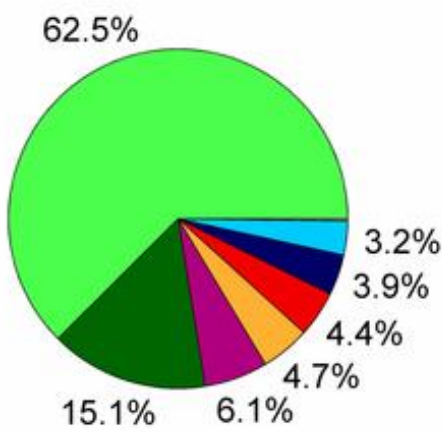

Nitrous Oxide

( $5 \%$ of total)

Fig. 2. Greenhouse Gas Emissions by Sector.

Source: European Environment Agency https://www.eea.europa.eu/data-and-maps/data/greenhouse-gas-emission-projections-for-6

This will be caused by changes in nitrogen concentration (Fig. 1,2). The underlying results of this process will be pollution and arising problems in varios ecosystems (Mikhaylov, 2018; Magazzino, 2016). Global temperature growth will cause the decrease of the share of minearals in legumes or the increase of the number of available chemical elements. The rate of mineralization can change the release of nitrogen.

A method of energy balance: this mode is mainly based on the energy balance model established under the law of conservation of energy. The energy balance equation is Equation 1:

$\mathrm{CdT} / \mathrm{dt}=\operatorname{Rad} \downarrow-\operatorname{Rad} \uparrow$ 
where $\mathrm{C}$ is the thermal inertia of land, ocean and the atmosphere, $\operatorname{Rad} \downarrow$ is the incoming radiation, $\operatorname{Rad} \uparrow$ is the outgoing radiation.

Equation 1 can be converted into Equation 2:

$\mathrm{C} \mathrm{dT} / \mathrm{dt}=\mathrm{Q}(1-\alpha)-\Delta \mathrm{I}-\mathrm{E}(\mathrm{F})$

where $\mathrm{Q}$ is the solar radiation, $\alpha$ is the reflectivity, $\Delta \mathrm{I}$ is the outgoing long-wave radiation, $\mathrm{E}(\mathrm{F})$ is the net energy flux along the circle of latitude.

The atmospheric $\mathrm{CO} 2$ equilibrium equation is as follows:

$$
\mathrm{dT} / \mathrm{dt}=\mathrm{Pfos}+\mathrm{Pbio}+\mathrm{Kma}(\mathrm{Nm}+\xi \mathrm{nm})+\mathrm{Kam}(\mathrm{Na}-\mathrm{na})+\mathrm{Fbi}, \mathrm{a}+\mathrm{Fa}, \mathrm{bi}+\mathrm{Fh}, \mathrm{a}
$$

where Pfos is the $\mathrm{CO} 2$ release rate of fossil fuels, Pbio is the rate of $\mathrm{CO} 2$ release due to land use change, Kma is the ocean atmosphere exchange coefficient, Kam is the atmosphere ocean exchange coefficient, $\mathrm{Nm}$ is the total amount carbon in the ocean, $\mathrm{Na}$ is the total carbon in the atmosphere, na is the atmospheric carbon increment, $\xi \mathrm{nm}$ is the ocean buffer factor, Fbi, a is the $\mathrm{CO} 2$ exchange flux from land to the atmosphere, Fa, bi is the $\mathrm{CO} 2$ exchange flux from the atmosphere to land, Fh, a is the $\mathrm{CO} 2$ exchange flux from soil humus to the atmosphere.

Climate change will cause efficiency in agriculture and forestry to fall. The impact of economic growth on the environment is observable. Moreover, it is likely to lead to a change in the model of precipitation (Marino et al., 2017; Meinshausen et al., 2009).

Russia ratified the Paris agreement on combating global climate change, which replaced the Kyoto Protocol. Countries participating in the Paris Agreement should prevent increasing the average global temperature by more than 2 degrees Celsius (Ogle et al., 2018; Perry et al., 2012).

\section{Results}

Russia has been a participant of the world climate agreements for many years: the Kyoto Protocol and the Paris Agreement. For Russia, the issue of climate change is very important. This is a chance for us to build an economy on new foundations: on energy efficiency, a low-carbon economy is a chance to move to a new level of development (Pugh et al., 2016; Shao et al., 2016). 


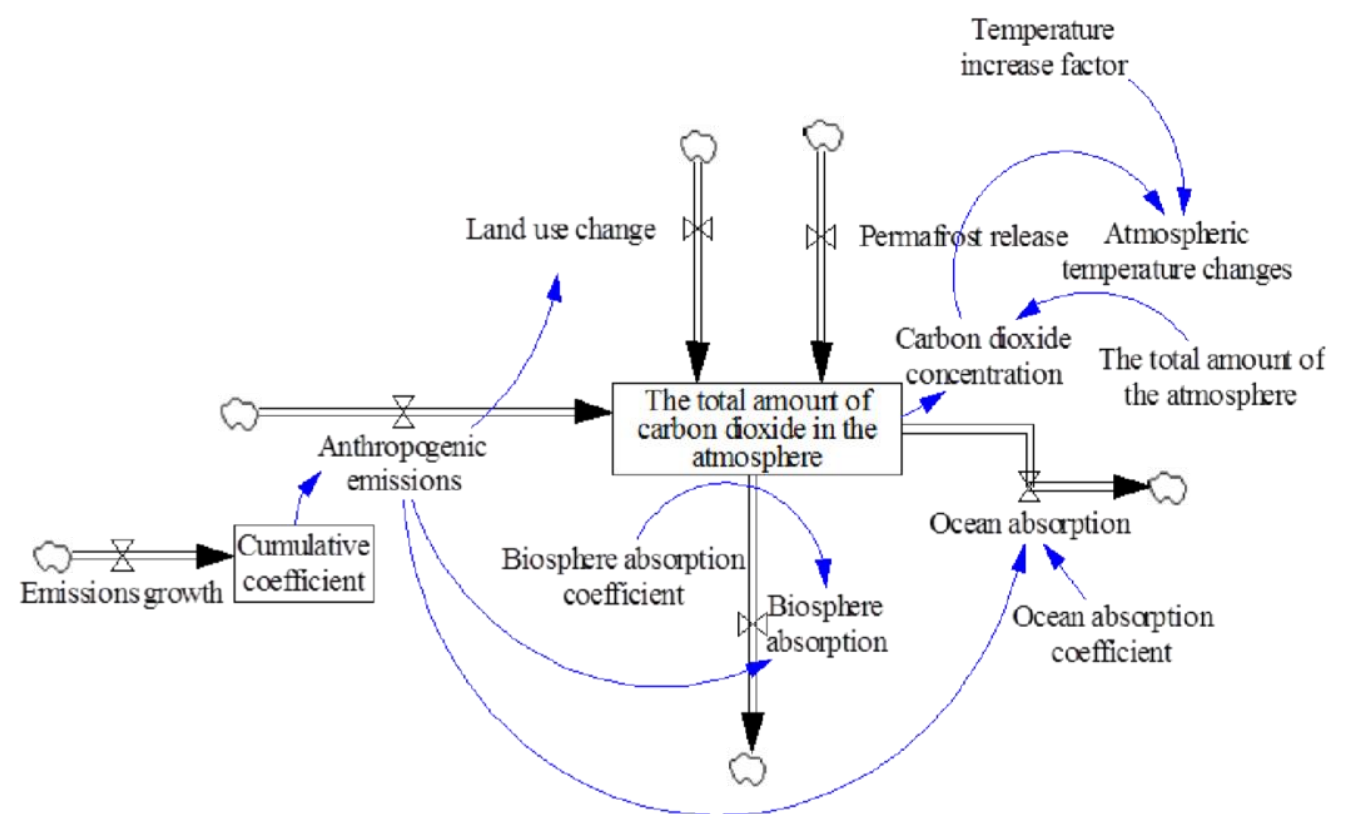

Fig. 3. Greenhouse Gas Emissions Scheme.

Source: author

The Paris Protocol poses several major challenges for all countries to achieve the goal. These goals are the end of the fossil fuels era, the development of low-carbon technologies and the adaptation of countries to climate change. Total emissions in 2017 were 2.2 times lower than in 1990 and decreased from 853 to 393 million tonnes of carbon equivalent.

From 1990 to 2017, carbon dioxide emissions decreased by 2.2 times (from 643 to 297 million tonnes of carbon equivalent), methane decreased by 2 times (from 151 to 73 million tonnes of carbon equivalent), nitrous oxide emissions dropped by 2.5 times (from 59 to 24 million tons of carbon equivalent).

The largest share of total greenhouse gas emissions in 1990 was carbon dioxide - about 75 percent. Methane emissions in 1990 were about 18 percent, and nitrous oxide were 7 percent of total emissions. This distribution practically did not change by 2017: carbon dioxide emissions accounted for 76 percent, methane for 18 percent, and nitrogen for 9 percent (Shi and Guo, 1997).

The greatest contribution to total greenhouse gas emissions comes from the extraction, production and consumption of energy resources; from 1990 to 2007 it fluctuated between 76 and 86 percent. The reduction in energy emissions from 1990 to 2007 was one of the most significant among all industries and amounted to 54 per cent. In 1990, net greenhouse gas absorption by forests was 73 million tonnes, and by 2007 it had been reduced to 44 million tonnes of carbon equivalent. The Russian government adopted the Energy Policy untill 2035 in the Sphere of Climate Change. This document is at the state level, which aims to limit the amount of CO2 emissions. Under the agreement with the EU, the country should also introduce an internal system for trade in greenhouse emissions. Russia needs to develop a quota allocation plan and introduce permits for greenhouse gas emissions in order to achieve this (Fig. 3, 4).

But before quotas can be earned, it is necessary to collect accurate data on the amount of $\mathrm{CO} 2$ is being emitted by industrial enterprises. For industrial regions, it is a good opportunity to improve the ecological situation and attract environmental investments. Industrial enterprises must decide on the means of reducing emissions (Sikharulidze et al., 2016; Stark et al., 2018). 


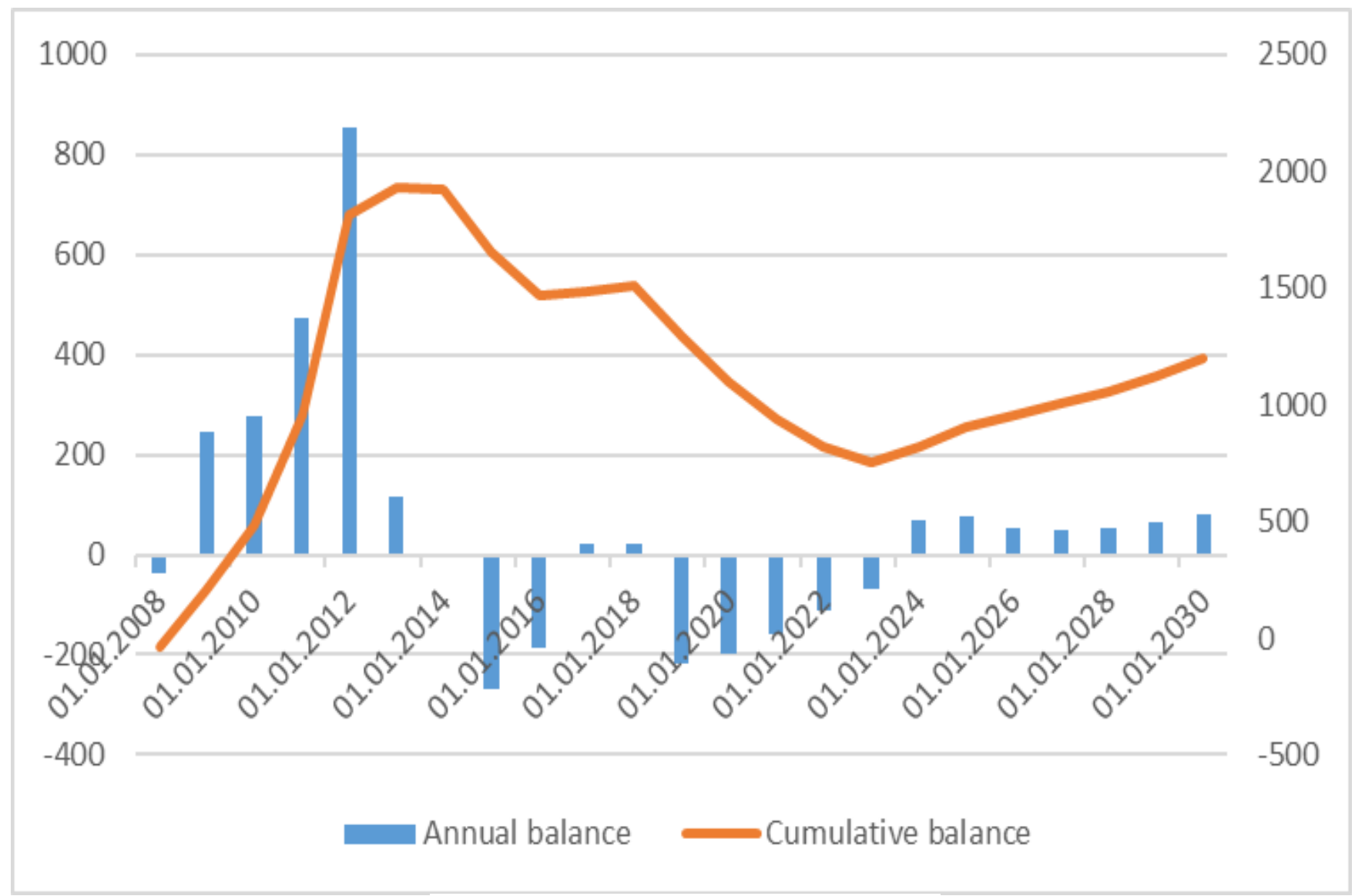

Fig. 4. Greenhouse Gas Emissions Balance Forecast.

Source: European Environment Agency https://www.eea.europa.eu/data-and-maps/data/greenhouse-gas-emission-projections-for-6

First, Russia will create a monitoring system for verification of emissions reporting. Then the Russian Federation will develop and begin to execute a plan of distributing quotas among six sectors of the economy. The quotas themselves are most likely to be paid. Having received a certain quota, the enterprise can implement measures aimed at reducing greenhouse gas emissions and selling surplus quota to another enterprise that lacks its own (Van den Berrgh and Botzen, 2015).

Furthermore, on a global scale, a World Bank program is now introducing pilot projects in six sectors of the economy in order to develop reporting templates for greenhouse gas emissions (Xu and Shang, 2016).

The quota system itself will force enterprises to either buy quotas or implement measures that will reduce emissions. This will make it possible to obtain quotas based on reliable data. The basis of the PMR project is to develop a monitoring and verification system for reporting data on such indicators as emissions, so that the developed scheme is the basis of the legislation. Rosneft is a company that represents the energy sector and is one of the largest emitters of greenhouse gas. Therefore our participation in the project is very important. And, of course, we are preparing for the introduction of an internal emission trading scheme in Russia. In the end result, this will lead to the implementation of measures aimed at reducing the burden on the environment.

The goal of this system is to reduce greenhouse gas emissions, as well as stimulate economic modernization. In the world about 20 per cent of $\mathrm{CO} 2$ emissions are given by machines with an internal combustion engine. At the 


\section{ENTREPRENEURSHIP AND SUSTAINABILITY ISSUES}

ISSN 2345-0282 (online) http://jssidoi.org/jesi/

2020 Volume 7 Number 4 (June)

http://doi.org/10.9770/jesi.2020.7.4(21)

same time, the number of machines in the world is growing. At the current pace there will be about 1 billion cars in the world until 2030, and well over a billion in 2050 (Tu, 2015; Zhang et al., 2018).

The Ministry of Infrastructure offers to release the following volumes of imported electric vehicles until 2021: vehicles from VAT - 16.8 per cent, collection to the Pension Fund - 4.8 per cent and excise duty - 109 euros. In addition, the government wants to make a tax rebate to car dealers on the income tax and reimburse part of the cost to the car buyer. The government wants to to cancel VAT and introduce a preferential land tax rate until 2028 for domestic manufacturers of electric vehicles, furthermore, collections to the Pension Fund will be canceled only until 2021. They also plan to cancel the import duty for electric cars' components and establish a delay from the paying of VAT for six months.

The nature of this phenomenon is explained by the different transparency of the atmosphere for radiation from space and from the surface of the planet. For the sun's rays, the atmosphere of the planet is transparent, like glass, and therefore they easily penetrate it. And for thermal radiation, the lower layers of the atmosphere are "impenetrable", too dense for passage. That is why some of the thermal radiation remains in the atmosphere, gradually sinking to the lowest layers of it. At the same time, the amount of greenhouse gases that condense the atmosphere is growing. Even at school we were taught that the main cause of the greenhouse effect is human activity. Evolution led us to industrialization, so we burn tons of coal, oil and gas, get fuel, fill roads with cars. The consequence of this is the release of greenhouse gases and substances into the atmosphere. Among them water vapor, methane, carbon dioxide, nitrogen oxide.

When we talk about the consequences of the greenhouse effect, we understand its influence on the Earth's climate. First of all, it is global warming. Many identify the concepts of "greenhouse effect" and "global warming", but they are not equal, but are interrelated: the first is the cause of the second. Global warming is directly related to the world's oceans. Here is an example of the two cause-effect relationship.

The average temperature of the planet grows; liquid begins to evaporate. This applies to the oceans: some scientists are afraid that in a couple of hundred years, they will begin to "dry out." At the same time, because of the high temperature, glaciers and sea ice will begin to melt actively in the near future. This will lead to an inevitable increase in the level of the World Ocean. We already observe regular floods in the coastal areas, but if the level of the World Ocean increases substantially, all the approximate parts of the land will be flooded, our harvest will die.

Greenhouse gases are steam (from water), carbon dioxide (carbon dioxide), methane, ozone. The prior is the main contributor to the formation of the greenhouse effect (up to 72 per cent). The next most important is carbon dioxide (9-26 per cent), methane and ozone share 4-9 and 3-7 per cent, respectively.

Recently, you can often hear about the greenhouse effect as a serious environmental problem. But this phenomenon has a positive side. Due to the fact that the greenhouse effect exists, the average temperature of our planet is about 15 degrees above zero. Without it, life on Earth would be impossible. The temperature could only be minus 18 .

The reason for the appearance of the effect is the activity of many volcanoes on the planet millions of years ago. At the same time, the concentration of water vapor and carbon dioxide in the atmosphere significantly increased. The concentration of the latter reached such a value that a super-strong greenhouse effect appeared. As a result, the water of the World Ocean almost boiled, its temperature became too high. 
The appearance of vegetation everywhere on the surface of the Earth caused a fairly rapid absorption of carbon dioxide. The accumulation of heat has decreased. Equilibrium was established. The average annual temperature on the surface of the planet turned out to be close to the present (Table 2).

Table 2. The contribution of atmospheric components to the greenhouse effect for various numerical models of the general circulation of the atmosphere.

\begin{tabular}{|c|c|c|c|c|c|}
\hline Source & BA & Cloudiness & BA+Cloudiness & $\mathrm{CO}_{2}$ & $\begin{array}{c}\text { Rest } \\
\text { greenhouse } \\
\text { gases }\end{array}$ \\
\hline Schmidt & $39,0-61,9$ & $14,5-36,3$ & $66,9-80,9$ & $14,0-24,3$ & $4,9-9,2$ \\
\hline The NASA model & $36-66$ & 16 & $66-85$ & $9-26$ & $2-8$ \\
\hline The average value & $37,5-64,0(\sim 50)$ & $15,3-36,3(\sim 25)$ & $66,5-83,0(\sim 75)$ & $11,5-25,2(\sim 20)$ & $3,5-8,6(\sim 5)$ \\
\hline
\end{tabular}

Source: author

Water vapor is not taken into account as a climatic factor. Direct emissions of water vapor from anthropogenic activities create prenegligibly small contribution to the radiation forcing.

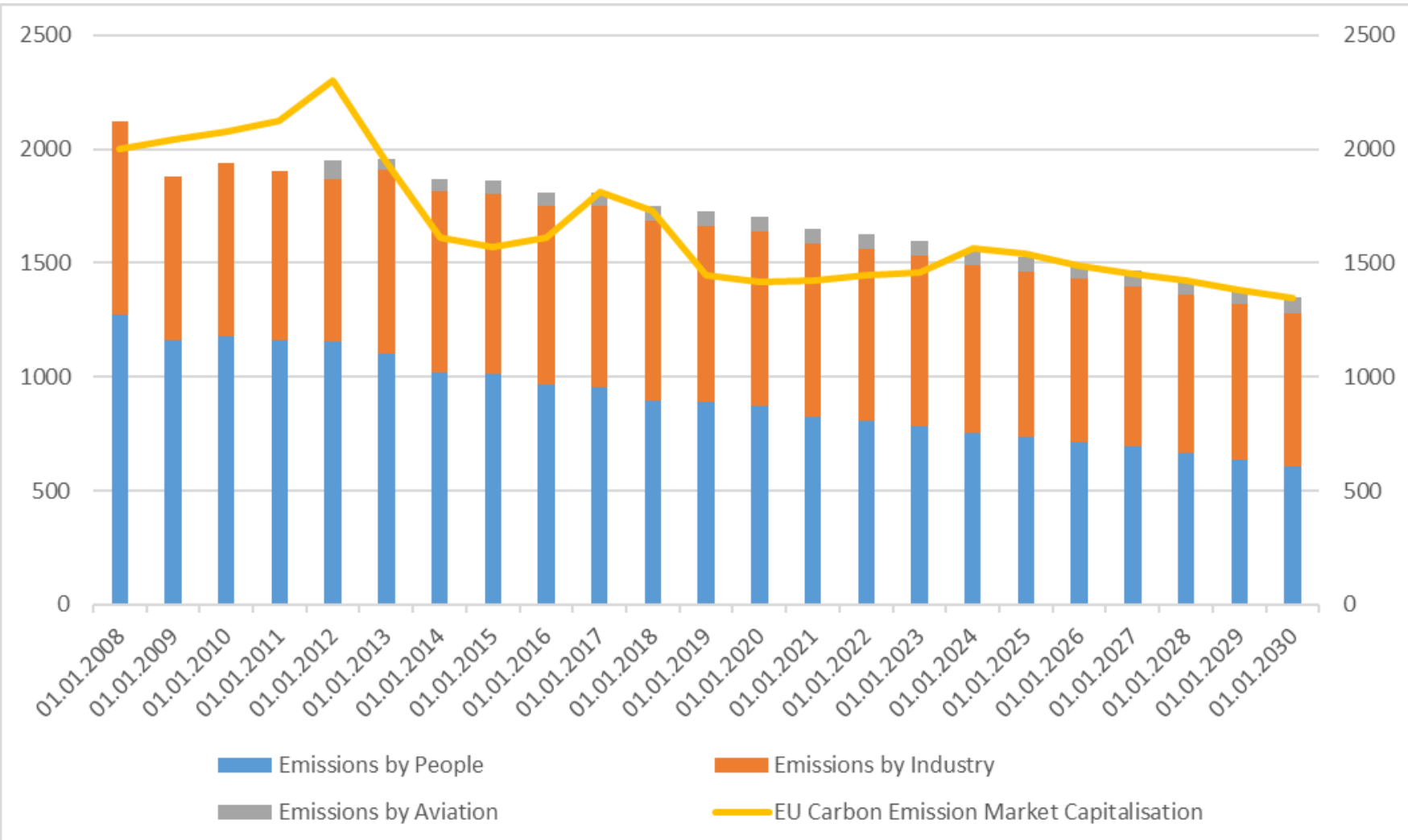

Fig. 5. Greenhouse Gas Emission Forecast by People and Industry.

Source: European Environment Agency https://www.eea.europa.eu/data-and-maps/data/greenhouse-gas-emission-projections-for-6c 


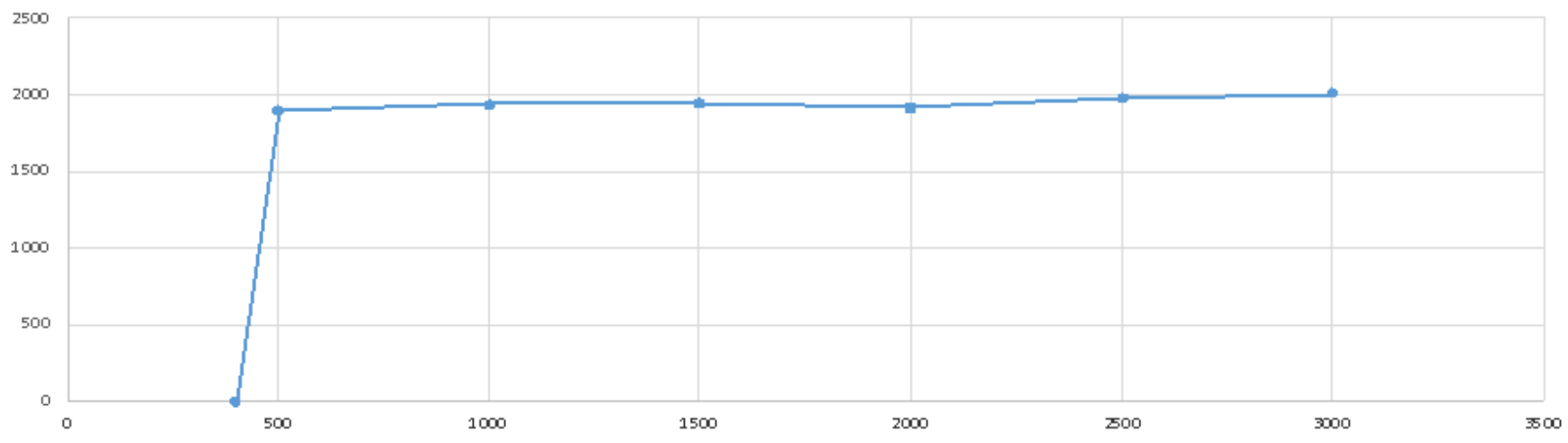

Fig. 6. Greenhouse Gas Emissions by Sector.

Source: European Environment Agency https://www.eea.europa.eu/data-and-maps/data/greenhouse-gas-emission-projections-for-6

Since water vapor content is directly dependent on evaporation, then, in fact, the trend of irretrievable water consumption can be considered as part of the trend of atmospheric moisture content. In the 20th century it was $0.013 \mathrm{~mm} /$ year. If we take into account that the area of the globe is 510 million $\mathrm{km}^{2}$, then the trend in the water use will be $39 \mathrm{~km}^{3}$ year $/ 510000000 \mathrm{~km}^{2}=0.0764 \mathrm{~mm} /$ year $($ Fig. 5, 6). 


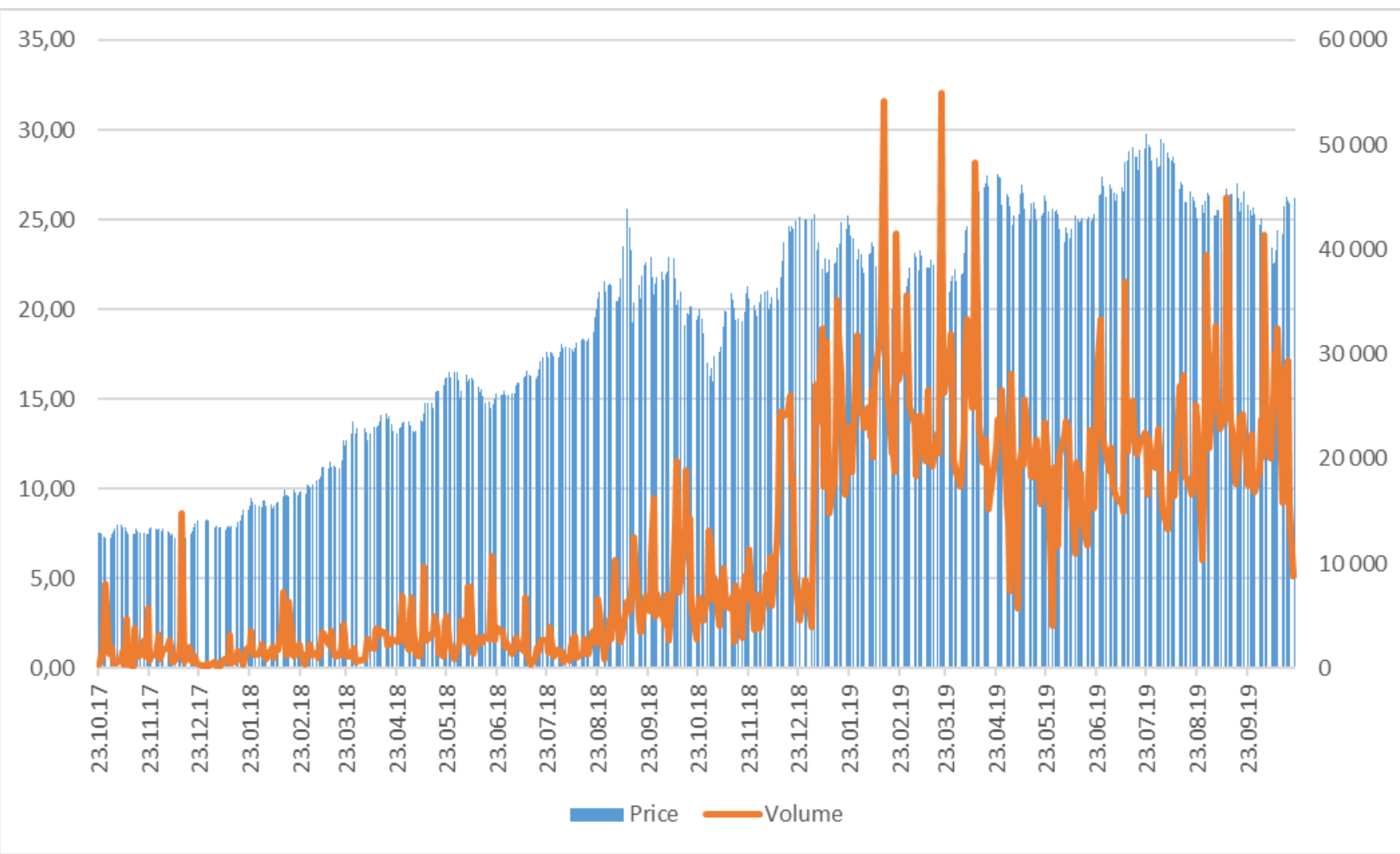

Fig. 7. European Union Allowance (EUA) price history.

Source: European Environment Agency https://www.eea.europa.eu/data-and-maps/data/greenhouse-gas-emission-projections-for-6

The consequences of the greenhouse effect can be harmful to humans: the melting of polar ice is the cause of rise in sea levels. As a result, coastal fertile lands are under water. If flooding occurs at high rates, there will be a serious threat to agriculture. The crops sink, the area of pastures is reduced, sources of fresh water disappear. First of all, the low-income strata of the population will suffer, whose life depends on their harvest, growth of domestic animals. Many coastal cities, including highly developed ones, may be under water in the future. For example, New York, St. Petersburg. Or whole countries. For example, the Netherlands. Such phenomena will cause the need for a massive displacement of human settlements. Scientists suggest that in 15 years the ocean level can rise by $0.1-0.3$ meters, and by the end of the 21 st century - by $0.3-1$ meter. To completely flood the above-mentioned cities under water, the level should rise by about 5 meters.

The increase in temperature of air leads to the fact that within the continents the period of snow presence is reduced. It begins to melt earlier, as soon as the rainy season ends. As a result, the soil is over-dried, unsuitable for growing crops. Lack of moisture is the cause of desertification of land. Experts argue that an average temperature increase of 1 degree in 10 years will lead to a reduction of forest areas by 100-200 million hectares. These lands will become steppes. The ocean covers 71 per cent of the surface area of our planet. As the air temperature rises, water also heats up. Evaporation increases significantly. And this is one of the main reasons for strengthening the greenhouse effect.

If the water level in the world ocean rises, temperature threatens biodiversity, many species of wildlife can disappear. The reason is the changes in their habitat. Not every species can successfully adapt to new conditions. 


\section{ENTREPRENEURSHIP AND SUSTAINABILITY ISSUES}

ISSN 2345-0282 (online) http://jssidoi.org/jesi/

2020 Volume 7 Number 4 (June)

http://doi.org/10.9770/jesi.2020.7.4(21)

The consequence of the disappearance of certain plants, animals, birds, other living things is the direct violation of food chains, the equilibrium of ecosystems.

The rise in water levels causes climate change. The boundaries of seasons are shifting, the number and intensity of storms, hurricanes, and precipitation increases. Stability of climate is the main condition for the existence of life on Earth. The stop in the greenhouse effect saves human civilization on the planet.

High air temperature can adversely affect people's health. Under such conditions, cardiovascular diseases worsen, respiratory organs suffer. Thermal anomalies lead to an increase in the number of injuries, the development of some psychological disorders. The rise in temperature entails a more rapid spread of many dangerous diseases, for example, malaria, encephalitis.

\section{Discussion}

Today, the problem of the greenhouse effect is a global ecological issue. Experts believe that the widespread adoption of the following measures will help solve the problem: changes in the use of energy sources. Reduction in the proportion and quantity of fossil fuels (containing carbon peat, coal) and oil. The transition to natural gas will significantly reduce $\mathrm{CO} 2$ emissions. An increase in the share of alternative energy sources (sun, wind, water) will reduce emissions, because these methods allow to receive energy without troubling the environment. When using them, harmful gases are not released. Change in energy policy. An increase in efficiency at power plants. Reduction of products' energy intensity at enterprises. Introduction of energy-saving technologies. Even the usual warming of houses' facades, window openings, heating plants give a significant result, decreasing the amount of emissions. Solving the problem at the enterprisal, industrial, state levels entails a global improvement of the situation. Everyone can contribute to solving this problem: energy saving, proper disposal of garbage, warming up their own home: development of technologies aimed at obtaining products in new, environmentally friendly ways; use of secondary resources, which is also one of the measures to reduce waste, the number and volume of landfills; restoration of forests, fighting fires in them, increasing the area as a way to reduce the concentration of carbon dioxide in the atmosphere.

Today, the fight against greenhouse gas emissions is at the international level. World summits devoted to this problem are being held, documents are being created aimed at organizing a global solution to the problem. Many scientists of the world are engaged in finding ways to reduce the greenhouse effect, maintaining balance and life on Earth.

It is desirable to invent ways to combat the greenhouse effect. For example, in the United Kingdom and the United States, groups of scientists have already created a device of active molecules that decompose greenhouse gases, and then turn them into useful aerosols. In those years there was not enough technically developed equipment that would allocate these molecules in a free form.

The results of this study support previous research conducted by (Marino et al., 2017; Meinshausen et al., 2009) which finds that carbon emissions and climate change is determined by utilization of networks as a source of opportunities and utilization of resources and their networks to provide service and respond to customers for change towards sustainability. Another research paper was supported in this study, stating that company's uniqueness through product creation may improve product success in customers' market through creation of climate change friendly products (Tu, 2015; Zhang et al., 2018).

This study also supports previous findings that product success in carbon emissions is influenced by company policy (Shi and Guo, 1997). In line with this discovery (Xu and Shang, 2016) carbon emission productivity in achieving performance through response to increasingly dynamic environment. 


\section{ENTREPRENEURSHIP AND SUSTAINABILITY ISSUES}

ISSN 2345-0282 (online) http://jssidoi.org/jesi/

2020 Volume 7 Number 4 (June)

http://doi.org/10.9770/jesi.2020.7.4(21)

\section{Conclusion}

Moreover, climate change is believed, by some researchers, to be company's new long-term breakthrough while maintaining competitive advantage and environmental sustainability (Isacs et al., 2016; Kohler et al., 2017). To enhance reputation and access to customers and wide and broad new markets, climate change is developed in corporate strategy, particularly by adopting greenhouse emissions friendly technology (Van den Berrgh and Botzen, 2015).

Although the carbon emessions study remains a debate among previous researchers, this issue is an interesting study in this article, where we develop and order to fill this gap of carbon emissions and climate change. This study proposes two forecasting models for greenhouse gas emissions balance forecast and greenhouse gas emission forecast until 2030 by industry to be a solution to the aforementioned research gap. This research also develops an empirical research model to further discuss their relationship.

\section{Contribution to the Body of knowledge}

This paper summarizes the literature review on carbon emissions and climate change into a new implication research. The empirical research shows the effect of carbon emissions on climate change. Therefore, this study suggests that an organization should allocate less carbon emissions into air in the next 10 years. This research makes at least three important contributions to the body of knowledge. The first contribution is the method of energy balance, particularly with regard to long term forecasts. The second contribution is achieved through empirical testing, determining a mediating role to prove that human and industrial carbon emissions fill the gap about emissions' role in climate change which remains a debate to previous researchers. The third one is that the paper found the trends in Greenhouse Gas Emission Forecast until 2030 by industry, people and aviation sector.

This research has limitations. The first one is the use of the method of energy balance. Another method can lead to different results. The second limitation is the source of data (European Environment Agency).

\section{References:}

Albergel, C., Calvet, J. C., Gibelin, A. L., Lafont, S., Roujean, J. L., Berne, C. (2010): Observed and modelled ecosystem respiration and gross primary production of a grassland in southwestern France. Biogeosciences 7(5): 1657-1668. www.biogeosciences.net/7/1657/2010/ https://doi.org/10.5194/bg-7-1657-2010

Alirezaei, M., Onat, N., Tatari, O., Abdel-Aty, M. (2017): The climate change-road safety-economy nexus: A system dynamics approach to understanding complex interdependencies. Systems 5(1): 1-24. https://doi.org/10.3390/systems5010006

Babič, M. (2017): New hybrid method of intelligent systems using to predict porosity of heat treatment materials with network and fractal geometry. Academic Journal of Manufacturing Engineering 15(1): 29-34.

Bayer, A. D., Pugh, T. A. M., Krause, A., Arneth, A. (2015): Historical and future quantification of terrestrial carbon sequestration from a greenhouse-gas-value perspective. Global Environmental Change 32: 153-164. https://doi.org/10.1016/j.gloenvcha.2015.03.004

Bergamaschi, P., Houweling, S., Segers, A., Krol, M., Frankenberg, C. (2013): Atmospheric CH4 in the first decade of the 21st century: inverse modeling analysis using SCIAMACHY satellite retrievals and NOAA surface measurements. Journal of Geophysical Research Atmospheres 118(13): 7350-7369. https://doi.org/10.1002/jgrd.50480 


\section{ENTREPRENEURSHIP AND SUSTAINABILITY ISSUES}

ISSN 2345-0282 (online) http://jssidoi.org/jesi/

2020 Volume 7 Number 4 (June)

http://doi.org/10.9770/jesi.2020.7.4(21)

Chehabeddine, M., Tvaronavičienè, M. (2020): Securing regional development. Insights into Regional Development 2(1): 430-442. http://doi.org/10.9770/IRD.2020.2.1(3)

Chen, J. W., Chen, X. S. (2016): No rosy picture for net-zero emissions goal by century end. Sino-Global Energy 21(6): 1-7.

Chen, Z., Yu, G., Zhu, X., Wang, Q., Niu, S., Hu, Z. (2015): Covariation between gross primary production and ecosystem respiration across space and the underlying mechanisms: a global synthesis. Agricultural and Forest Meteorology 203: 180-190. https://doi.org/10.1016/j.agrformet.2015.01.012

Cloy, J. M. (2018): Greenhouse gas sources and sinks. Encyclopedia of the Anthropocene 2: 391-400.

Cui, X. Q., Wang, K., Zou, J. (2016): Impact of $2^{\circ} \mathrm{C}$ and $1.5^{\circ} \mathrm{C}$ target to INDC and longterm emissions pathway of China. China Population Resources and Environment 26(12): 1-7.

Denisova, V. (2019). Energy efficiency as a way to ecological safety: evidence from Russia. International Journal of Energy Economics and Policy 9(5): 32-37. https://doi.org/10.32479/ijeep.7903

Denisova, V., Mikhaylov, A., \& Lopatin, E. (2019). Blockchain Infrastructure and Growth of Global Power Consumption. International Journal of Energy Economics and Policy 9(4): 22-29. https://doi.org/10.32479/ijeep.7685

Elzen, M. D., Höhne, N. (2008): Reductions of greenhouse gas emissions in Annex I and non-Annex I countries for meeting concentration stabilisation targets. Climatic Change 91(3-4): 249-274. https://doi.org/10.1007/s10584-008-9484-z

Elzen, M. D., Höhne, N. (2010): Sharing the reduction effort to limit global warming to $2^{\circ} \mathrm{C}$. Climate Policy 10 : $247-260$. https://doi.org/10.3763/cpol.2009.0678A

European Environment Agency https://www.eea.europa.eu/data-and-maps/data/greenhouse-gas-emission-projections-for-6

Fan, Y., Zhang, X. B., Zhu, L. (2010): Estimating the macroeconomic cost of CO2 emission abatement in China based on multi-objective programming. Advances in Climate Change Research 6(2): 130-135. https://doi.org/10.3724/SP.J.1248.2010.00027

Frolking, S., Roulet, N., Fuglestvedt, J. (2006): How northern peatlands influence the earth's radiative budget: sustained methane emission versus sustained carbon sequestration. Journal of Geophysical Research Biogeosciences 111: G01008. https://doi.org/10.1029/2005JG000091

Gotovsky, M., Gotovsky, A., Mikhailov, V., Kolpakov, S., Lychakov, V., Sukhorukov, Y. (2018): Formic acid cycle as partial alternative to Allam cycle less expensive and simpler. Tecnica Italiana - Italian Journal of Engineering Science 61(1-2): 49-54.

Huang, S. K., Kuo, L., Chou, K. L. (2016): The applicability of marginal abatement cost approach: A comprehensive review. Journal of Cleaner Production 127: 59-71. https://doi.org/10.1016/j.jclepro.2016.04.013

Inamdar, A. K., Ramanathan, V. (1994): Physics of greenhouse effect and convection in warm oceans. Journal of Climate 7: 715-731. https://doi.org/10.1175/1520-0442(1994)007<0715:POGEAC >2.0.CO;2

Isacs, L., Finnveden, G., Dahllöf, L., Håkansson, C., Petersson, L., Steen, B., Swanströmc, L., Wikström, A. (2016): Choosing a monetary value of greenhouse gases in assessment tools: a comprehensive review. Journal of Cleaner Production 127: 37-48. https://doi.org/10.1016/j.jclepro.2016.03.163

Köhler, P., Nehrbass-Ahles, C., Schmitt, J., Stocker, T. F., Fischer, H. A. (2017): 156 kyr smoothed history of the atmospheric greenhouse gases $\mathrm{CO} 2, \mathrm{CH} 4$, and $\mathrm{N} 2 \mathrm{O}$ and their radiative forcing. Earth System Science Data 9(1): 363-387. http://hdl.handle.net/10013/epic.51252.d001

Levin, I. (2012): Earth science: The balance of the carbon budget. Nature 488(7409): 35-36. https://doi.org/10.1038/488035a

Li, H. Y. (2017): On China's carbon emission reduction after the Paris Climate Conference. Modern Business 11: 163-164.

Lisin, A. (2020). Biofuel Energy in the Post-oil Era. International Journal of Energy Economics and Policy 10(2): 194-199. https://doi.org/10.32479/ijeep.8769 


\section{ENTREPRENEURSHIP AND SUSTAINABILITY ISSUES}

ISSN 2345-0282 (online) http://jssidoi.org/jesi/

2020 Volume 7 Number 4 (June)

http://doi.org/10.9770/jesi.2020.7.4(21)

Lopatin, E. (2019a). Methodological Approaches to Research Resource Saving Industrial Enterprises. International Journal of Energy Economics and Policy 9(4); 181-187. https://doi.org/10.32479/ijeep.7740

Lopatin, E. (2019b). Assessment of Russian banking system performance and sustainability. Banks and Bank Systems 14(3): 202-211. https://doi.org/10.21511/bbs.14(3).2019.17

Meynkhard, A. (2020). Priorities of Russian Energy Policy in Russian-Chinese Relations. International Journal of Energy Economics and Policy 10(1): 65-71. https://doi.org/10.32479/ijeep.8507

Meynkhard, A. (2019a). Energy Efficient Development Model for Regions of the Russian Federation: Evidence of Crypto Mining. International Journal of Energy Economics and Policy 9(4): 16-21. https://doi.org/10.32479/ijeep.7759

Meynkhard, A. (2019b). Fair market value of bitcoin: halving effect. Investment Management and Financial Innovations 16(4): 72-85. https://doi.org/10.21511/imfi.16(4).2019.07

Mikhaylov, A. (2018). Pricing in Oil Market and Using Probit Model for Analysis of Stock Market Effects. International Journal of Energy Economics and Policy 8(2): 69-73. Retrieved from https:// www.econjournals.com/index.php/ijeep/article/view/5846

Magazzino, C. (2016): The relationship between real GDP, CO2 emissions, and energy use in the GCC countries: a time series approach. Social Science Electronic Publishing 4(1): 1-20. https://doi.org/10.1080/23322039.2016.1152729

Marino, C., Nucara, A., Nucera, G., Pietrafesa, M. (2017): Economic, energetic and environmental analysis of the waste management system of Reggio Calabria. International Journal of Heat and Technology 35(S1): S108-S116.

Meinshausen, M., Meinshausen, N., Hare, W., Raper, S. C. B., Frieler, K., Knutti, R., Frame, D. J., Allen, M. R. (2009): Greenhouse-gas emission targets for limiting global warming to $2^{\circ} \mathrm{C}$. Nature, 458(7242): 58-62. https://doi.org/10.1038/nature08017

Moumen, Z., El Idrissi, N.E.A., Tvaronavičienè, M., Lahrach, A. (2019): Water security and sustainable development. Insights into Regional Development 1(4); 301-317. https://doi.org/10.9770/ird.2019.1.4(2)

Ogle, S. M., Domke, G., Kurz, W. A., Rocha, M. T., Huffman, T., Swan, A. (2018): Delineating managed land for reporting national greenhouse gas emissions and removals to the United Nations framework convention on climate change. Carbon Balance \& Management 13(1): 9-14. https://doi.org/10.1186/s13021-018-0095-3

Perry, L. G., Andersen, D. C., Reynolds, L. V., Nelson, S. M., Shafroth, P. B. (2012): Vulnerability of riparian ecosystems to elevated CO2 and climate change in arid and semiarid western North America. Global Change Biology 18(3): 821-842. https://doi.org/10.1111/j.1365$\underline{2486.2011 .02588 . x}$

Pugh, T. A. M., Müller, C., Arneth, A., Haverd, V., Smith, B. (2016): Key knowledge and data gaps in modelling the influence of CO2 concentration on the terrestrial carbon sink. Journal of Plant Physiology 203: 3-15. https://doi.org/10.1016/j.jplph.2016.05.001

Shao, J., Zhou, X., Luo, Y., Li, B., Aurela, M., Billesbach, D. (2016): Direct and indirect effects of climatic variations on the interannual variability in net ecosystem exchange across terrestrial ecosystems. Tellus B: Chemical and Physical Meteorology 68: 30575. https://doi.org/10.3402/tellusb.v68.30575

Shi, G. Y., Guo, J. D. (1997): One-dimensional analysis of global carbon cycle. Scientia Atmospherica Sinica 21(4): 413-425.

Sikharulidze, A., Timilsina, G. R., Karapoghosyan, E., Shatvoryan, S. (2016): How do we prioritize the GHG mitigation options? Development of a marginal abatement cost curve for the building sector in Armenia and Georgia (Inglés). Gastroenterology 140(5): S666. https://doi.org/10.1596/1813-9450-7703

Stark, J. S., Roden, N. P., Johnstone, G. J., Milnes, M., Black, J. G., Whiteside, S. (2018): Carbonate chemistry of an in-situ free-ocean $\mathrm{CO} 2$ enrichment experiment (Antfoce) in comparison to short term variation in Antarctic coastal waters. Scientific Reports 8(1): 2816. https://doi.org/10.1038/s41598-018-21029-1

Tu, R. H. (2005): Introduction to United Nations framework convention on climate change and its Kyoto protocol and their negotiation process. Environmental Protection (3): 65-71.

Van den Bergh, J. C. J. M., Botzen, W. J. W. (2015): Monetary valuation of the social cost of CO2 emissions: a critical survey. Ecological Economics 114: 33-46. https://doi.org/10.1016/j.ecolecon.2015.03.015 


\title{
ENTREPRENEURSHIP AND SUSTAINABILITY ISSUES
}

ISSN 2345-0282 (online) http://jssidoi.org/jesi/

2020 Volume 7 Number 4 (June)

http://doi.org/10.9770/jesi.2020.7.4(21)

$\mathrm{Xu}$, M., Shang, H. (2016): Contribution of soil respiration to the global carbon equation. Journal of Plant Physiology 203: 16-28. https://doi.org/10.1016/i.jplph.2016.08.007

Zhang, J. X., Sun, W. G., Niu, F. S., Wang, L., Zhao, Y. W., Han, M. M. (2018). Atmospheric sulfuric acid leaching thermodynamics from metallurgical zinc-bearing dust sludge. International Journal of Heat and Technology 36(1): 229-236.

\begin{abstract}
Alexey MIKHAYLOV received a Ph.D. in Economics in the field of Finance from Institute of Economics, Russian Academy of Sciences, Russia (2013), and a Diploma in Economics from Financial University under the Government of the Russian Federation (2009). He holds a position of assistant professor of Financial Markets and Banks Department in Financial University under the Government of the Russian Federation, Russia. He is an author of 14 scientific publications and conference papers indexed in SCOPUS and Web of Science, author of more than 40 scientific publications indexed in relevant scientific databases and author of 8 scientific monographs. He also became Deputy Director of Monetary Relations Research Center (2019) and Head of laboratory of Financial markets department (2017) in Financial University under the Government of the Russian Federation. Membership: ACI Russia.
\end{abstract}

ORCID ID: https://orcid.org/0000-0003-2478-0307

Nikita MOISEEV is Ph.D. in Economics and an associate professor at Plekhanov Russian University of Economics. Main scientific interests are forecasting time series of socio-economic processes; macro-level modeling; multi-factor regression analysis; Bayesian econometrics; econometric modeling; machine learning. He developed a system for numerical evaluation of economic projects based on cross-industry balance using combined methods of computer optimization. He was awarded the diploma of the European Scientific and Industrial Chamber "Di Merito" \#000445 by the order of 01.11.2016.

ORCID ID: https://orcid.org/0000-0002-5632-0404

Kirill ALESHIN is Ph.D. in Economics, a member of the Directorate as well as Academic Council of the Institute for African Studies, Russian Academy of Sciences (RAS). He is also a group head and senior research fellow at the Centre for global and strategic studies of the same institution. Prior to obtaining his Ph.D., he graduated from MGIMO University, Russia, and University of St. Gallen, Switzerland. The scope of scientific interests: national economies and international economic relations of the African and CIS states; strategic interests of Russia and other countries in Africa; the interaction of business and state on the international arena.

ORCID ID: https://orcid.org/0000-0002-2749-1044

Thomas BURKHARDT is graduated in physics (Diploma 1990) and economics (Diploma 1992). He has Doctoral degree 1994 summa cum laude from Göttingen University. Since 2001 he holds the chair of finance at Koblenz-Landau University, Campus Koblenz. Primary research interests are financial decision making, asset management, derivatives, and long term investment decisions, including forest investments. Preferred methods include mathematical modeling and optimization as well as economic experiments.

ORCID ID: https://orcid.org/0000-0002-8410-088X

Copyright (C) 2020 by author(s) and VsI Entrepreneurship and Sustainability Center

This work is licensed under the Creative Commons Attribution International License (CC BY).

http://creativecommons.org/licenses/by/4.0/

cC) (†) Open Access 